\title{
PCR-based identification of Neospora caninum in the umbilical cord of a newborn calf in Brazil
}

\author{
Nilton Azevedo da Cunha Filho ${ }^{1 *}$ Plínio Aguiar de Oliveira ${ }^{1}$ Fernando Caetano de Oliveira $^{2}$ \\ Felipe Geraldo Pappen $^{3}$ Cintia Lidiane Guidotti Aguiar ${ }^{1}$ Alceu Gonçalves dos Santos Junior ${ }^{2}$ \\ André Luis Costa-da-Silva ${ }^{4,5}$ Fabio Pereira Leivas Leite ${ }^{6}$ Nara Amélia da Rosa Farias ${ }^{1}$
}

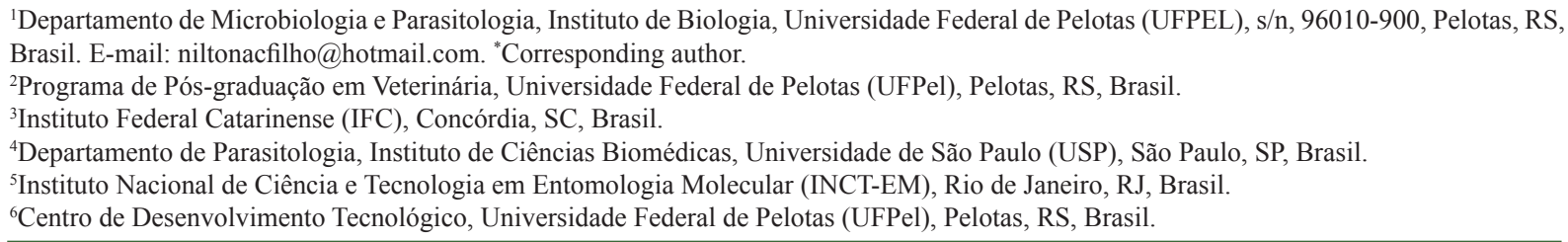

ABSTRACT: This study was conducted at a beef cattle breeding farm in the far southern region of Brazil. The birth of a calf with unilateral corneal opacity was immediately reported to the Laboratory of Parasitology, in the Universidade Federal de Pelotas, Rio Grande do Sul, Brazil; blood was collected from the cow and calf before colostrum intake. The umbilical cords from this calf and from six other healthy animals were collected. Serological examination, utilizing an indirect fluorescent antibody test, was done using a cut-off point of 1:100. Polymerase chain reaction (PCR) was also performed using the umbilical cord samples. Serological tests showed that the calf was positive for Neospora caninum at birth, with a titer of 1:1600; a titer of 1:3200 was reported in the dam. PCR, using umbilical cord tissue from the affected animal, was positive for the presence of this parasite, and the molecular identity of the amplified product was confirmed by sequencing. Therefore, the detection of N. caninum DNA in the umbilical cord represents a novel alternative test for the diagnosis of this parasitic infection in newborn calves that are clinically suspected to have neosporosis.

Key words: Neospora caninum, calves, umbilical cord, bovine.

\section{Identificação de Neospora caninum por PCR em cordão umbilical de bezerros recém nascido no Brasil}

RESUMO: O estudo foi realizado em uma fazenda de criação de gado de corte na região do extremo sul do Brasil. O nascimento de um bezerro com opacidade unilateral da córnea foi imediatamente relatado ao Laboratório de Parasitologia da Universidade Federal de Pelotas (RS) e coletou-se sangue da vaca e do bezerro antes da ingestão do colostro. Foram coletados sangue e cordão umbilical do bezerro com opacidade na córnea bem como de outros seis bezerros aparentemente saudáveis antes da ingestão de colostro. Foram realizados exames sorológicos utilizando o teste indireto de anticorpos fluorescentes (IFAT) com ponto de corte de 1: 100 e reação em cadeia da polimerase (PCR). O resultado dos exames sorológicos mostraram que o bezerro foi positivo para $N$. caninum ao nascer com titulação de 1:1600 e o de sua mãe foi de 1:3200 na IFAT. A PCR do cordão umbilical foi positiva para o agente no animal com opacidade córnea unilateral e a identidade molecular do produto amplificado foi confirmada por sequenciamento. A detecção de DNA de N. caninum no cordão umbilical é uma nova alternativa para o diagnóstico deste agente em bezerros recém-nascidos com suspeita clínica de neosporose.

Palavras-chave: Neospora caninum, bezerros, cordão umbelical,bovinos.

\section{INTRODUCTION}

Neospora caninum is considered a major cause of reproductive disease in bovines (ANDERSON et al., 2000). It is responsible for major economic losses worldwide in both dairy and beef cattle industries, with associated costs reaching up to 9.7 million euros per year in dairy cow herds in Switzerland (HÄSLER et al., 2006). Dogs have been considered definitive hosts of $N$. caninum, as they eliminate oocysts in stool specimens after the ingestion of infected tissues from several intermediate hosts (MCALLISTER et al., 1998). Studies have demonstrated that coyotes (Canis latrans) (GONDIM et al., 2004), dingoes (Canis lupus dingo) (KING et al., 2010), and gray wolves (Canis lupus) (DUBEY et al., 2011) are also definitive hosts of this protozoan. It is believed that red foxes (Vulpes vulpes) are also hosts, as $N$. caninum oocysts have been reported in their feces (WAPENAAR et al., 2006). The seroprevalence of $N$. caninum in rural areas has been reported to range from $2.8 \%$ in beef cattle in New Zealand (TENNENT-BROWN et al., 2000) to $76.9 \%$ in dairy cattle in Colombia (CEDEÑO \& BENAVIDES, 2013).

Dijkstra et al., (2002) reported that when a young dog is introduced to a farm or upon the birth of the dog's offspring on the farm, the risk of bovine abortion increases. The presence of 
dogs in bovine breeding farms was considered an important risk factor for the horizontal transmission of $N$. caninum and subsequent abortion in different countries (PARÉ et al., 1998). Vertical transmission in bovines is considered the most important route of transmission, as the probability of offspring infection is approximately 95\% (BARTELS et al., 2007).

Abortion is the major clinical sign of neosporosis in bovines; this can happen during the third month of gestation, but mostly occurs between the $5^{\text {th }}$ and $6^{\text {th }}$ months (DUBEY, 2003). The first report of abortion as a result of $N$. caninum infection in dairy cattle was in New Mexico (THILSTED \& DUBEY, 1989).

Diagnosis of bovine neosporosis is based on the detection of typical lesions in fetal tissues (non-suppurative encephalitis), and the subsequent detection of the parasite by immunoperoxidase or polymerase chain reaction (PCR) methods (DUBEY, 2003; WOUDA \& BUXTON, 2007).

PCR is very sensitive and can detect the presence of the agent even in a very small amount of sample. $N$. caninum DNA has been detected in different tissues such as the brain and lung of several animals (HOLMDAHL \& MATTSON, 1996; LALLY et al., 1996), bovine semen (ORTEGA-MORA et al., 2003), and aborted fetuses (ŞUTEU et al., 2010). The objective of this study was to evaluate the umbilical cord of a calf born with unilateral corneal opacity for the presence of $N$. caninum genomic DNA.

\section{MATERIALS AND METHODS}

\section{Animals}

Animals used in this study were born on a beef cattle farm located at the geographical coordinates $31^{\circ} 45^{\prime} 48^{\prime \prime} \mathrm{S}, 52^{\circ} 29^{\prime} 02^{\prime \prime} \mathrm{W}$, and a mean altitude of $21 \mathrm{~m}$. This farm was chosen because it has an $N$. caninum seroprevalence of $18.4 \%(50 / 272)$ in reproducing cows.

The birth of a Braford cross calf with unilateral corneal opacity was reported to the Laboratory of Parasitology in Universidade Federal de Pelotas (UFPel), Rio Grande do Sul, Brazil. Animals were immediately taken to the facilities and umbilical cord and blood samples were collected.

\section{Blood and umbilical cord sampling}

Blood from the calf was taken before colostrum intake, and was collected by puncturing the jugular vein using 5-ml sterile tubes without an anticoagulant. A cross section of the umbilical cord was collected using a sterile scalpel. To compare PCR results of healthy calves with those of animals showing clinical signs of neosporosis, the umbilical cords of six calves born on the same day were also collected. Both blood serum and umbilical cord samples were stored at $-20^{\circ} \mathrm{C}$ until laboratory analyses. This study was approved by the Research Ethics Committee on Animal Experimentation of Universidade Federal de Pelotas (UFPel), protocol number 8682.

\section{Indirect fluorescent antibody test (IFAT)}

$N$. caninum antibodies were identified by IFAT according to the technique of BJÖRKMAN \& UGGLA (1999). Sensitized slides with NC-Bahia strain tachyzoites, using a cut-off point of 1:100, were used and diluted to the maximum titer when necessary (AGUIAR et al., 2011). Positive and negative serum controls were used in each reaction.

\section{Differential diagnosis}

To rule out other infectious diseases such as bovine herpesvirus type 1 (BHV-1), bovine viral diarrhea virus (BVDV), and toxoplasmosis, which can cause eye problems such as corneal opacity, cataracts (Potgieter, 2004), and conjunctivitis (Weiblen, 1992), the sera of the calf and its dam were tested. For this, the neutralization technique was used to test for the presence of specific antibodies against bovine herpesvirus type 1 (BHV-1), bovine viral diarrhea virus (BVDV), and Toxoplasma gondii, using IFAT.

\section{DNA extraction}

DNA extraction from umbilical cords was performed after maceration in liquid nitrogen. The Easy-DNA (Invitrogen) kit was used, employing protocol 3, which is designed for a small number of cells and tissues. For DNA extraction, $100 \mathrm{mg}$ of umbilical cord tissue was weighed using an accurate analytical scale; $350 \mu 1$ of cell lysis solution was added, which was followed by shaking in vortex mixer. Samples were incubated at $65^{\circ} \mathrm{C}$ for 10 minutes. After incubation, $150 \mu 1$ of precipitation solution was added under vortex shaking. Then, $500 \mu 1$ of chloroform was added, and the sample was shaken in a vortexer to separate the phases (aqueous phase, interphase, and chloroform). For DNA precipitation, only the aqueous phase (the upper phase) was collected into a sterile microcentrifuge tube. A total of $1 \mathrm{ml}$ of ethanol $(100 \%)$ was added, and the mixture was incubated on ice for 30 minutes. After incubation, the samples were centrifuged at $10,000 \times g$ for 15 minutes; ethanol was removed and the pellet was preserved at the bottom of the tube. A total of $500 \mu$ l of ethanol $(80 \%)$ was added, and the sample was centrifuged again at $10,000 \times g$. Ethanol was removed and the pellet was kept. The 
pellet was then centrifuged at $10,000 \times g$ for three minutes to remove residual ethanol. The material was then suspended in $100 \mu 1$ of TE (tris-EDTA) buffer with $2 \mu \mathrm{l}$ of RNAse and incubated at $37^{\circ} \mathrm{C}$ for 30 minutes. The concentration of genomic DNA was determined by spectrophotometry at $280 \mathrm{~nm}$. DNA was stored at $-20^{\circ} \mathrm{C}$ until molecular analyses.

\section{PCR}

PCR was performed using the specific primers $\mathrm{Np} 6+/ \mathrm{Np} 21+$ for $N$. caninum, which amplify the Nc-5 region (MÜLLER et al., 1996). The NC-1 strain (DUBEY et al., 1988) was used as the positive control, and the brains of infection-free mice provided the negative control. Each mixture of the reaction consisted of $2.5 \mu \mathrm{l}$ buffer, $1 \mu \mathrm{l}$ dNTPs, $0.75 \mu \mathrm{MgCl}$ (50mM), $1 \mu \mathrm{l} \mathrm{Np6+}(10 \mu \mathrm{M}), 1 \mu \mathrm{l} \mathrm{Np} 21+(10 \mu \mathrm{M})$, $0.2 \mu \mathrm{l}$ Taq polymerase, $2 \mu \mathrm{l}$ DNA, and $16.5 \mu \mathrm{l}$ ultrapure water. Amplification was performed using a BioCycler. Cycling parameters for amplification consisted of an initial denaturation at $94^{\circ} \mathrm{C}$ for 3 minutes, followed by 40 cycles of denaturation at $94^{\circ} \mathrm{C}$ for 1 minute, hybridization at $50^{\circ} \mathrm{C}$ for 1 minute, and extension at $72^{\circ} \mathrm{C}$ for 2 minutes, with a final extension at $72^{\circ} \mathrm{C}$ for 5 minutes. PCR products were subjected to electrophoresis using a $1.5 \%$ agarose gel and were visualized under UV light to detect the presence of the specific fragment (337bp). The amplified fragment was extracted using the Wizard SV Gel and PCR Clean-Up System (Promega) and sent to ACTGene Molecular Analysis (Porto Alegre, Brazil) for DNA sequencing. Sequences were analyzed using BIOEDIT software and compared those from the NCBI database using the BLAST algorithm. The consensus sequence was deposited into the GENBANK (accession number: KY849114).

\section{RESULTS AND DISCUSSION}

The tested animal was born with unilateral corneal opacity and exhibited $N$. caninum antibody titers of $1: 1600$ at birth, whereas the titer of the dam at birth was 1:3200 for the same agent. De MEERSCHMAN et al. (2002) reported a tight association between high levels of dam antibodies and histopathological lesions in fetus showing signs of neosporosis. PEREIRA-BUENO et al. (2000) reported an increase in antibody levels in the dam in the second gestational trimester. This finding is related to an increase in the parasite multiplication rate, suggesting evidence of vertical transmission and enhanced probability of abortion. DUBEY \& SCHARES (2006) demonstrated that calves start to mount an immune response to microorganisms during the aforementioned gestational period; however, this would not be enough to protect them from the pathogenic effects of the agent. This might have occurred in the subject animal of this study, considering that the calf was born with clinical signs of congenital neosporosis (DUBEY et al., 2006). Based on differential diagnosis of other diseases that can cause eye problems in calves, none of the animals evaluated were positive.

By performing PCR on the DNA template from the umbilical cord of the calf born with unilateral corneal opacity, a fragment of approximately $327 \mathrm{bp}$ was amplified (Figure 1), whereas no amplification was observed in healthy calves. Sequencing results with significant coverage confirmed that the amplified fragment was from $N$. caninum. The consensus sequence of the amplified fragment (307bp) best matched deposited sequences from this agent, with $73-75 \%$ identity. SANTANA et al. (2010) reported that it is possible to detect $N$. caninum DNA in the blood of heifers that are chronically infected during different periods of gestation. In addition, it was demonstrated that cyst reactivation occurs as of the first gestational trimester and that this eventually affects the fetus. The consequences to the fetus depend on the gestational period during which transmission occurred.

Detection of $N$. caninum in the liver, placenta, kidney, and brain of aborted fetuses as well as in adult bovine animals has been achieved using PCR (SHIVAPRASAD et al., 1989; WOUDA et al., 1997). However, tissue distribution was not reported to be equal, considering that most tachyzoites were reported in brain (85\%), liver (26\%), and heart (14\%) (WOUDA et al., 1997).

The detection of $N$. caninum DNA in the umbilical cords of calves with neurological changes might be a very useful tool to confirm disease status. This is in accordance with a study by BASZLER et al. (1999), wherein it was reported that a PCR assay for the identification of $N$. caninum in bovine fetuses that were spontaneously aborted, together with assessing histopathological changes, is a very efficient method to confirm disease diagnosis. This technique was shown to have $100 \%$ sensitivity using formalin-fixed tissues (13 of 13 fetuses investigated were positive by PCR) and $77 \%$ sensitivity using fresh brain samples (10 of 13 investigated tissues were positive by PCR).

In another study conducted on a dairy cattle farm, using 3-7-month-old aborted fetuses, $33 \%$ were reported to be positive by PCR (3/9). In 


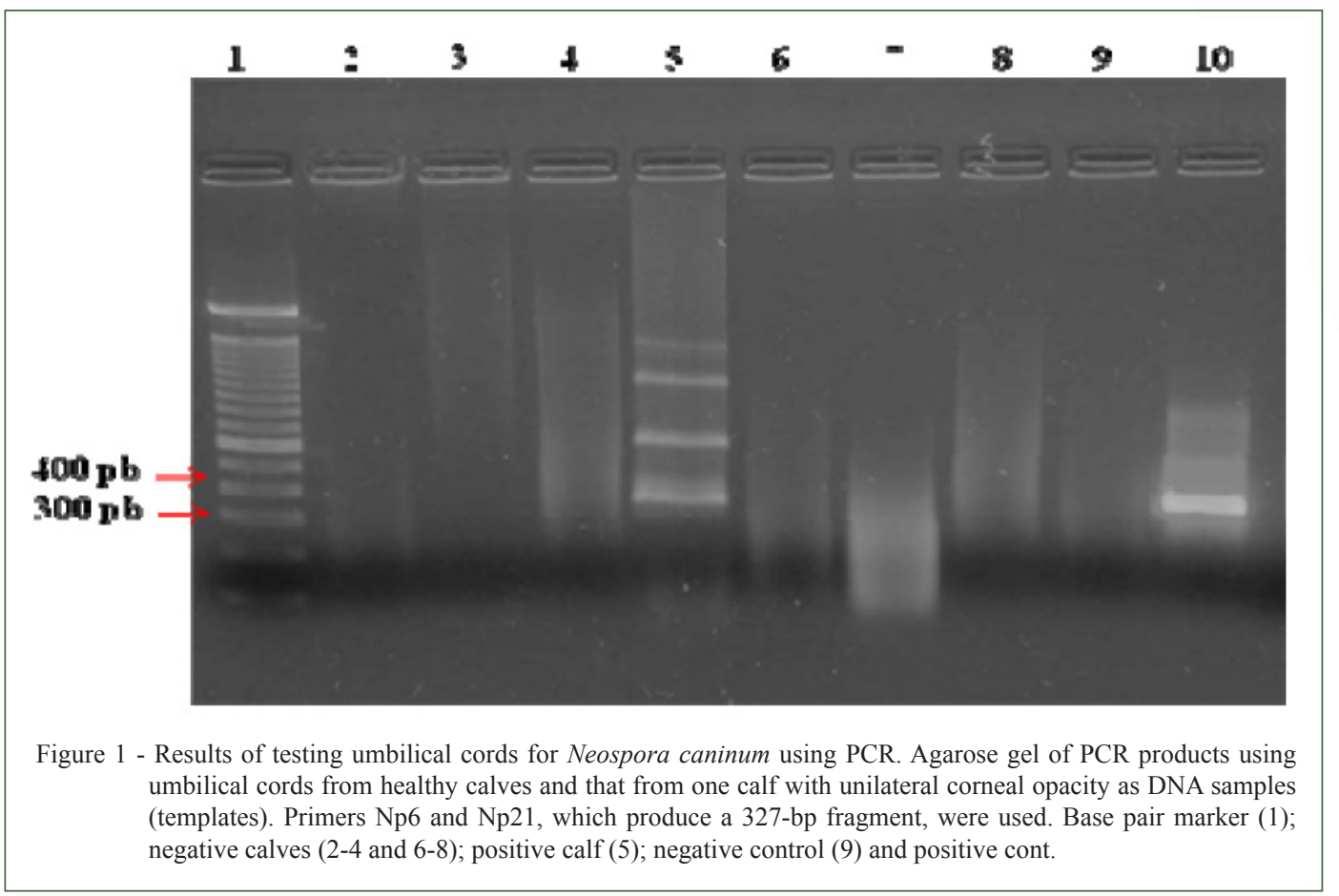

this study, neither histological lesions compatible with neosporosis nor parasite cysts were found. We believed that advanced autolysis in the tissues could be the reason that no relevant histopathological changes were found (SUTEU et al., 2010).

This is the first report of the detection of $N$. caninum DNA in the umbilical cord of calves born with neosporosis-compatible clinical signs.

\section{CONCLUSION}

We successfully reported the first detection of $N$. caninum DNA from the umbilical cord of a calf from a beef cattle breeding farm in Brazil. This provided a new alternative diagnostic test for $N$. caninum in newborn calves with clinical signs of neosporosis.

\section{CONFLICT OF INTEREST STATEMENT}

The authors declared that there is no conflict of interest that could be perceived as prejudicing the impartiality of the research reported.

\section{ACKNOWLEDGEMENTS}

The authors gratefully acknowledge Conselho Nacional de Desenvolvimento Científico e Tecnológico (CNPq), Coordenação de Aperfeiçoamento de Pessoal de Nível Superior (CAPES) for financial support.

\section{REFERENCES}

AGUIAR, D.M. et al. Seroprevalence and risk factors associated to Neospora caninum in female bovines from the western São Paulo State, Brazil. Arquivos do Instituto Biológico, v.78, p.183-189, 2011. Available from: <http://www.biologico.sp.gov.br/docs/arq/ v78_2/aguiar.pdf $>$. Accessed: Jan. 20, 2016. doi: 10.1590/S0100736X2012001000011.

ANDERSON, M.L. et al. Neosporosis in cattle. Animal Reproduction Science, v.60-61, p.417-431, 2000. Available from: <http://www. sciencedirect.com/science/article/pii/S0378432000001172>. Accessed: Feb. 20, 2016. doi: 10.1016/S0378-4320(00)00117-2.

BARTELS, C.J. etal. Quantification of vertical and horizontal transmission of Neospora caninum infection in Dutch dairy herds. Veterinary Parasitology. v.148, n.2, p.83-92, 2007. Available from: <http://www. sciencedirect.com/science/article/pii/S0304401707002798>. Accessed: Jan. 15, 2017. doi: 10.1016/j.vetpar.2007.06.004.

BASZLER, T.V. et al. Detection by PCR of Neospora caninum in fetal tissues from spontaneous bovine abortions. Journal of Clinical Microbiology, v.37, n.12, p.4059-4064, 1999. Available from: <http:// www.ncbi.nlm.nih.gov/pmc/articles/PMC85881/>. Accessed: Feb. 15, 2016.

BJÖRKMAN, C.; UGGLA, A. Serological diagnosis of Neospora caninum infection. International Journal Parasitology, v.29, p.1497-1507, 1999. Available from: <http://www.sciencedirect. com/science/article/pii/S0020751999001150>. Accessed: Feb. 15, 2016. doi: 10.1016/S0020-7519(99)00115-0.

CEDEÑO, Q.D.; BENAVIDES, B.B. Seroprevalence and risk factors associated to Neospora caninum in dairy cattle herds in the 
municipality of Pasto, Colombia. Revista MVZ Córdoba, v.18, n.1, p.3311-3316, 2013. Available from: <http://revistas.unicordoba.edu. co/revistamvz/mvz-181/v18n1a9.pdf $>$. Accessed: May 15, 2016.

De MEERSCHMAN, F. et al. Fetal infection with Neospora caninum in dairy and beef cattle in Belgium. Theriogenology, v.58, p.933-945, 2002. Avaliable from: <http://www.sciencedirect. com/science/article/pii/S0093691X02009342>. Accessed: Aug. 16. 2016. doi: 10.1016/S0093-691X(02)00934-2.

DIJKSTRA, T.H. et al. Point source exposure of cattle to Neospora caninum consistent with periods of common housing and feeding and related to the introduction of a dog. Veterinary Parasitology, v.105, n.2, p.89-98, 2002. Available from: <https://www.researchgate. net/publication/11462842_Point_source_exposure_of_cattle_to Neospora_caninum_consistent_with_periods_of_common_housing and feeding and related to the introduction of a $\operatorname{dog}>$. Accessed: July 10. 2016. doi: 10.1016/S0304-4017(02)00009-2.

DUBEY, J.P. et al. A new recognized fatal protozoan disease of dogs. Journal of the American Veterinary Medical Association, v.192, n.9, p.1269-1285, 1988.

DUBEY, J.P. Neosporosis in cattle. Journal of Parasitology, v.89, p.42-56, 2003. Available from: <http://www.sciencedirect. com/science/article/pii/S0749072005000344>. Accessed: May 14, 2016. doi: 10.1016/j.cvfa.2005.03.004.

DUBEY, J.P. Review of Neospora caninum and neosporosis in animals. Korean Journal of Parasitology, v.41, p.1-16, 2003. Available from: <http://www.ncbi.nlm.nih.gov/pmc/articles/PMC2717477/>. Accessed: Apr. 6, 2016. doi: 10.3347/kjp.2003.41.1.1.

DUBEY, J.P.; SCHARES, G. Diagnosis of bovine neosporosis. Veterinary Parasitology, v.140, p.1-34, 2006. Available from: $<$ http://naldc.nal.usda.gov/download/10166/>. Accessed: June 05, 2016. doi: 10.1016/j.vetpar.2006.03.035.

DUBEY, J.P. et al. Pathogenesis of bovine neosporosis. Journal Comparative Pathology, v.134, n.4, p.267-289, 2006. Available from: $<\mathrm{http}: / / \mathrm{www}$. sciencedirect.com/science/article/ pii/S0021997505001350>. Accessed: Dec. 05, 2016. doi: 10.1016/j.jcpa.2005.11.004.

DUBEY, J.P. et al. Gray wolf (Canis lupus) is a natural definitive host for Neospora caninum. Veterinary Parasitology, v.181, p.382-387, 2011. Available from: <http://www.sciencedirect. com/science/article/pii/S0304401711003566>. Accessed: Apr. 06 , 2016. doi: 10.1016/j.vetpar.2011.05.018.

GONDIM, L.F.P. et al. Coyotes (Canis latrans) are definitive hosts of Neospora caninum. International Journal for Parasitology, v.34, p.159-161, 2004. Available from: <http://www.sciencedirect. com/science/article/pii/S0020751904000025>. Accessed: Apr. 09, 2016. doi: 10.1016/j.jpara.2004.01.001.

HÄSLER, B. et al. Financial analysis of various strategies for the control of Neospora caninum in dairy cattle in Switzerland. Preventive Veterinary Medicine, v.77, n.3-4, p.230-253, 2006. Available from: $<$ http://www. sciencedirect.com/science/article/pii/S0167587706001784>. Accessed: Aug. 06, 2016. doi: 10.1016/j.prevetmed.2006.07.006.

HOLMDAHL, O.J.M.; MATTSON, J. Rapid and sensitive identification of Neospora caninum by in vitro amplification of the internal transcribed spacer 1. Parasitology, v.112, p.177-182, 1996. doi: $10.1017 / \mathrm{S} 0031182000084742$.
KING, J.S. et al. Australian dingoes are definitive hosts of Neospora caninum. International Journal for Parasitology, v.40, p.945-950, 2010. Available from: <http://www.sciencedirect. com/science/article/pii/S0020751910000445> . Accessed: Aug. 06, 2016. doi: 10.1016/j.ijpara.2010.01.008.

LALLY, N.C. et al. Development of a polymerase chain reaction assay for the diagnosis of neosporosis using the Neospora caninum 14-3-3 gene. Molecular and Biochemical Parasitology v.75, p.169-178, 1996. Available from: <http://www.sciencedirect.com/ science/article/pii/0166685195025308>. Acessed: Aug. 8. 2016. doi: 10.1016/0166-6851(95)02530-8.

MCALLISTER, M.M. et al. Dogs are definitive hosts of Neospora caninum. International Journal for Parasitology, v.28, p.14731475, 1998. Available from: <http://www.sciencedirect.com/ science/article/pii/S0020751998001386>. Accessed: Apr. 07. 2016. doi: 10.1016/S0020-7519(98)00138-6.

MÜLLER, N. et al. Diagnosis of Neospora caninum and Toxoplasma gondii infection by PCR and DNA hybridization immunoassay. Journal of Clinical Microbiology, v.34, p.28502852, 1996. Available from: <http://www.ncbi.nlm.nih.gov/pmc/ articles/PMC229420/pdf/342850.pdf>. Accessed: Apr. 07, 2016.

ORTEGA-MORA, L.M. et al. Detection of Neospora caninum in semen of bulls. Veterinary Parasitology, v.117, p.301-308, 2003. Available from: $<$ http://www.sciencedirect.com/science/article/pii/ S0304401703003844>. Accessed: Apr. 08, 2016. doi: 10.1016/j. vetpar.2003.09.015.

PARÉ, J. et al. Seroepidemiologic study of Neospora caninum in dairy herds. Journal American Veterinary Medicine Association, v.213, p.1595-1598, 1998.

PEREIRA-BUENO, J. et al. Observational studies in Neospora caninum infected dairy cattle: pattern of transmission and age-related antibody fluctuations. International Journal of Parasitology, v.30, p.906-909, 2000.

POTGIETER, L.N.D. Bovine viral diarrhoea and mucosal disease. Infectious diseases of livestock. 2.ed. Southern África, Cape Town: Oxford University, V.2. p. 946-969. Veterinary Clinics of North America: Food Animal Practice, v.11, n.3, p.501-520, 2004.

SANTANA, O.I. et al. Neospora caninum: Detección de ADN en sangre durante la primera gestación de vaquillas infectadas naturalmente. Veterinaria México, v.41, n.2, p.131-137, 2010. Available from: $<$ http://www.scielo.org.mx/scielo.php?script=sci arttext\&pid $=$ S0301-50922010000200006\&lng $=$ es \&nrm $=$ iso $>$. Accessed: Aug. 05, 2016.

SSUTEU, O. et al. First identification of Neospora caninum by PCR in aborted bovine fetuses in Romania. Parasitology Research, v.106, p.719-722, 2010. Available from: <http://link.springer. com/article/10.1007\%2Fs00436-009-1684-6>. Accessed: Aug. 10, 2016. doi: 10.1007/s00436-009-1684-6.

SHIVAPRASAD, H.L. et al. A Neospora-like protozoon found in an aborted bovine placenta. Veterinary Parasitology, v.34, p.145-148, 1989. Available from: <http://www.sciencedirect. com/science/article/pii/030440178990174X $>$. Accessed: Aug. 10, 2016. doi: 10.1016/0304-4017(89)90174-X.

TENNENT-BROWN, B.S. et al. Prevalence of Neospora antibodies in beef cattle in New Zealand. New Zealand Veterinary Journal, 
v.48, p.14-150, 2000. Available from: < http://www.tandfonline.com/ doi/pdf/10.1080/00480169.2000.36182?needAccess $=$ true\&redire ct=1 . Accessed: Apr. 06. 2016. doi: 10.1080/00480169.2000.36182.

THILSTED, J.P.; DUBEY, J.P. Neosporosis-like abortions in a herd of dairy cattle. Journal of Veterinary Diagnostic Investigation, v.1, p.205-209, 1989. Available from: < http://vdi. sagepub.com/content/1/3/205.long>. Accessed: Aug. 08, 2016. doi: $10.1177 / 104063878900100301$

WAPENAAR, W. at al. Neospora caninum-like oocysts observed in feces of free-ranging red foxes (Vulpes vulpes) and coyotes (Canis latrans). Journal of Parasitology, v.92, n.6, p.1270-1274, 2006. Available from: <http://www.bioone.org/doi/10.1645/GE913R.1?url_ver=Z39.882003\&rfr_id=ori\%3Arid\%3Acrossref. org\&rfr_dat $=$ cr_pub\%3Dpubmed\&>. Accessed: Feb. 12, 2015.
WEIBLEN, R. Doenças víricas que interferem na produção leiteira. In: CHARLES, T.P.; FURLONG, J. (Eds.). Doenças dos bovinos de leite adultos. Coronel Pacheco, MG: Embrapa - CNPGL, 1996. p.45-62.

WOUDA, W. et al. Bovine fetal neosporosis: a comparison of epizootic and sporadic abortion cases and different age classes with regard to lesion severity an immunohistochemical identification of organisms in brain, heart, and liver. Journal of Veterinary Diagnostic Investigation, v.9, p.180-185, 1997. Available from: <http://vdi. sagepub.com/content/9/2/180.long $>$. Accessed: Aug. 12, 2016. doi: 10.1177/104063879700900212.

WOUDA, W.; BUXTON, D. Immunohistochemistry. In: ORTEGAMORA, LM. et al. (Eds.). Protozoal abortion in farm ruminants: guidelines for diagnosis and control. Gateshead: CAB International, Athenaeum, 2007. p.57-58. doi: 10.1079/9781845932114.0000. 
Erratum

\section{Erratum}

In the article "PCR-based identification of Neospora caninum in the umbilical cord of a newborn calf in Brazil", published in Ciência Rural, volume 47, number 7, DOI http://dx.doi.org/10.1590/0103-8478cr20160876, were added the authors Alceu Gonçalves dos Santos Junior and Fabio Pereira Leivas Leite. 